\title{
Assessing Impact of Liberalization on Financial Performance Sustainability of Indian Pharmaceutical Industry using Structure Conduct Performance Model
}

\author{
Dr. Pankaj Talreja a ${ }^{\text {, Dr. Seema Gupta }}{ }^{\text {b }}$ \\ ${ }^{a}$ Research Scholar, Amity College of Commerce and Finance (ACCF), Amity University Noida \\ ${ }^{\mathrm{b}}$ Professor, Amity College of Commerce and Finance, Noida \\ Email: adrpankajtalreja@gmail.com, sgupta18@amity.edu
}

Article History: Received: 10 November 2020; Revised 12 January 2021 Accepted: 27 January 2021; Published online: 5 April 2021

\begin{abstract}
The Indian Pharmaceutical Industry is ranked third largest by volume and fourteenth by value. It thus accounts for $10 \%$ of world's production by volume and $1.5 \%$ by value according to Department of Pharmaceuticals, Government of India. Recognizing the immense potential for growth of Indian pharmaceutical industry and its direct impact on Indian economy the present paper tries to analyze the market structure of the Indian pharmaceutical firms and assess how the sustainable profitability of firms is affected using structure conduct performance model. The study founds out the sustainable profitability is statistically related to firm size, export and import, raw material expenses, power use and wage intensity but there seems to be insignificant effect of market share and mergers and acquisition on firm's performance in terms of sustainable profitability.

Keywords:
\end{abstract}

\section{Introduction}

The Indian pharmaceutical sector has immense potential for growth and its direct impact on Indian economy warrants to lookup the market structure of the Indian pharmaceutical firms. It is quite important to determine the market structure and its relationship with performance in terms of sustainable profitability across markets for both goods and services. The critical role of understanding the market structure is evident in determining effective economic policy related to anti-trust laws, intellectual property rights, industry competition acts and regulations and which has an overall lasting effects on international trade andties.

It is important to understand whether the highly concentrated markets charge higher prices and make more production gain or do they become attractive to entry of newer firms and result in higher competition. How do the Indian pharmaceutical firms make barriers to entry whether by making strategic investments in advertisement or by increasing Research and development? The proposed research tries to throw some light on these unanswered questions in context of Indian pharmaceutical sector. How does the market structure become conducive for collusion and mergers?

The critical role of understanding the market structure is crucial for making effective economic policy that impacts many industries simultaneously, so it becomes essential to develop insights topharmaceutical market structure and its determinants before framing intellectual property rights, or laws related to competition acts. Intellectual property rights and competition laws have profound impact on the market structure and thereby are important to change firm behavior. Moreover, it also impacts the growth and profitability of the industry. Therefore, it is not so surprising that economist have studied the relationship between market structure, its impact on firm behavior and performance in the field of industrial organization (IO). Historically to a large extent the work of two economists, Edward Mason and Joe Bain during1930 have paved thepathtothisareaofresearchemphasizingonfirmbehaviorandmarketstructure.Thestructure- conduct-performance framework became the mainstream methodology for empirically studying the market structure and its determinants in industrial organization during1950-1980.

After1980withtheemergenceofNewIndustrialOrganizationthegametheoreticalapproachwas also introduced as an alternate approach to study the marketstructure.

Though there is empirical literature on the subject on SCP paradigm for various industriesaround the world but the work on the market structure of Indian pharmaceutical firms is scarce.

\section{Objective:}

Industrial growth plays a vital role in the development of the economy, therefore it is crucialto develop 
evidence based policies which promote industrial growth and restricts unjust monopolistic policies. This requires a clear understanding of the market structure to formulate effective economic policies. The proposed paper tries toexamine the effect of firm's market share and market concentration on the sustainable financial performance of Indian pharmaceutical companies measured in terms of profitability.

\section{Literature Review:}

Based on Mishra and Chandra (2010), sustainable profitability of firm inversely related to its market share. This contradicts the general perception that firms with larger market share have high sustainable profitability also especially in the long run, this is true. The plausible reason of this phenomenon could be greater entry of new firms seeing higher profit margins. This could also be true in case of $X$ inefficiency.TheauthorusesSCPframeworktounderstandtheimpactofmergersandacquisitions (M\&A) on financial performance of the firms. A regression analysis is done using independent variables as current firm size, current market share and size, current export and import intensity, and lagged variables for mergers and acquisitions, selling intensity, $R \& D$ intensity, foreign technology purchase intensity and dependent variable as current sustainable profitability of a firm. Anh, T. T., Binh, D. T. T., \& Duong, N. V. (2014) revisited the SCP paradigm to understand the impact of market concentration and market share on sustainable profitability in case of Vietnamese firms. A positive correlation was found between market concentration and market share of rims and sustainable profitability of firm.

Ali (2021) showed that size determinants affect the supply chain finance of the Indian pharmaceutical industry.

Isola and Mesagan (2016) studied the relationship between market structure and performance of the pharmaceutical industry of Nigeria. It used market share to determine industry's efficiency, pre-tax return on asset to assess financial performance. Lim and Rokhim (2020) also examined the factors impacting the profitability of Indonesian pharmaceutical companies after the national health insurance policy implementation.

McDonald(1999)usedtimeseriesanalysistostudythedeterminantsofsustainable profitability of Australian manufacturing firms. He found out significant positive impact of firm's market concentration on its performance but fails to find any significant impact of market share on sustainable profitability of firm. According to Feeny S. and Rogers M. (1999) worked to understand the role of market share and market concentration and diversification on sustainable profitability of 722 Australian firm's data. Using simple regression analysis, they found a positive relationship between market concentration (using four firm concentration methods) and sustainable profitability but there was non-monotonic significant relationship between firm's market share and its sustainable profitability. When market share increased up to $30 \%$ profit declines while beyond $30 \%$ market share the sustainable profitability of firm increased.

There are many studies which estimate impact of India's signing of the TRIPs agreement on the pharmaceutical industry (Sahu, S.K. 2014). Basant, R. (2011) argue that evaluation of the IP regulation in developing countries should be based on how they facilitate capability building of domestic firms. Kale, D., and Little, S. (2007) have shown that the Indian pharmaceutical industry has followed an imitation trajectory. As a result of new patent regimes the industry is trying to develop $\mathrm{R} \& \mathrm{D}$ capabilities.

The variables representing structural components, conduct factors and performance variables are based on literature documented in this field byMishraP.\&ChandraT.(2010); Anh, T. T., Binh, D. T. T., \& Duong, N. V. (2014). Firm Size is generally has positive impact on profitability due to economies of scale and has beenwell documented by (Hall and Weiss, 1967; Scherer, 1973; Majumdar, 1997). Market Size is used as measure of the demand of company's product. Market Share is expected to increase firm's profitability and has been found to have U-shaped relationship (Feeny and Rogers 1999).McDonald (1999) found no significant relationship between profitability and market share of Australian manufacturing firms. Mergers and Acquisitions increase the market power (Steiner, 1975, Chatterjee, 1986).

\subsection{Theoretical Model of SCP Paradigm:}

Cournotduopolymodelformalizesthetheoreticalrelationbetweenmarketstructurewhichaffects firm's conduct and its performance. The following equation shows that the Lerner Index (L) is directly related to firm's market share $\left(\mathrm{si}_{1}\right)$, price elasticity of demand $(\varepsilon)$ and its conjectural variation $\left(\lambda_{i}\right)$ :

$$
\mathrm{Li}=\underline{\mathrm{P}(\mathrm{Q})-\mathrm{MC}(\mathrm{qi})}=\underline{\mathrm{si}(1+\lambda \mathrm{i})}
$$

$$
\mathrm{P}(\mathrm{Q})
$$

where $\lambda_{\mathrm{j}}=\underline{d q j}$

$$
d q i
$$


$\lambda_{\mathrm{i}}$ is the conjectural variation which measures the output response of the rival firms. It is also a measure of the degree of collusion.

The conjectural variation variable is determined by other factors:

$$
\square i \square \square f 1 \square \square C j, B j, X i j \square
$$

Where $\mathrm{Cj}$ is a measure of seller concentration, $\mathrm{Bj}$ a measure of barrier to entry and $\mathrm{Xij}$ are set of industry or firm characteristics. The equation shows the relationship between market structure and firm conduct.

Using the first and second equation a link can be seen between market structure and firm performance

$$
\mathrm{Li} \square f 2 \square \mathrm{s}, \varepsilon, C j, B j, X i j \square
$$

There is a correlation between measures of sustainable profitability $\square \square$ i $\square$ and Learner's Index.

$$
\square \mathrm{i} \square f 2 \square \mathrm{s}, \varepsilon, C j, B j, X i j \square
$$

There is ample literature on industrial organization (e.g., Bain, 1951; Schmalensee, 1989; Gupta, 1983; Baker; Khambampati (1996) and Woodward, 1998) that have used econometric method to empirically estimate the SCP relationships. Cabral and Mata(1991) also shows conventional entry barriers to new firms in Portugal industry are economies to scale, capital structure and product differentiation. The study by Anh, T. T., Binh, D. T. T., \& Duong, N. V. (2014) has used SCP method on Vietnam industrial data to show that advertising makes a barrier to entry of the new firms. Many studies show that market concentration enhances performance in banking sector (Edward, 1964; Brucker, 1970; Vernon, 1971; Gilbert, 1984; Evanoff and Fortier, 1988; Molyneux and Thornton, 1992; Lloyad-Williams et al., 1994; Molyneux\& Forbes, 1995; Katib, 2004). Demsetz (1974) and Berger (1995) showed that larger market shares lead to efficiency and reduce costs.

\section{Methodology:}

The data would be analyzed using the empirical specification of S-C-P Structure, Conduct and Performance model.

The Structure-Conduct-Performance (SCP) methodology consists of three main components:

- Structure: Structure denotes the market structure. In this component the variables that represent market structure are included. For instance, seller concentration, barriers toentry in a market and productdifferentiation.

- Conduct: Conduct is representative for a firm's behavior. The variables included in this category capture firm behavior in terms of pricing policies, collusion or competition, advertising, mergers and acquisitions, research and development expenditure and technologyinvestment.

- $\quad$ Performance: Performance denotes the factors assessing outcome. The variables which are used for measuring performance are profit and price-costmargin.

The SCP paradigm specifies causal relationships between market structure, firm conduct and performanceofthefirm. Theyhaveaunidirectionallinkwhichshowsmarketstructuredetermines a firm's conduct and its conduct further determines itsperformance:

\section{Structure $\rightarrow$ Conduct $\rightarrow$ Performance}

The SCP paradigm originated in 1939 from the work of Edward Mason, aHarvard economist and his student Joe S. Bain. They used SCP methodology to determine empirically how pricing and production policies of firms are formed and how does market share determines these policy decisionsofafirm.MasonworkedonindustryorfirmspecificdatawhileBainusedSCPparadigm on industry-leveldata.

With the evolution of new theories in industrial organization literature the unidirectional framework of SCP method suggested by Mason and Bain was changed to multidirectional relationships ${ }^{1}$. So, there can be dual causalities between any two of these SCP factors. Further there have been additional factors involving taxes, investment, subsidies and export, import policies which are taken into account in SCP model for finding causal relationships.

\section{Data Source:}

Data on a set of selected pharmaceutical companies is collected from PROWESS database of Centre for Monitoring Indian Economy (CMIE), Mumbai. 


\subsection{Time frame Selected for Study: 1990 to 2016}

The chosen time period is relevant from the context of policy reforms and amendments in Indian Patent Act and Rules. Post TRIPS agreement Indian Patent Act, 1970 underwent important amendments in the year 1999, 2002 and 2005. Moreover, Indian Patent Rules were amended in the year 2003, 2005, 2006, 2012, 2013, 2014 and 2016. The proposed research paper tries to capturethe effect of these reforms in Indian Patent Act and rules on the market structure of the Indian pharmaceuticalfirms.

\subsection{The SCP Model for Indian Pharmaceutical Enterprises}

In this proposed research paper, we revisited the SCP paradigm for Indian Pharmaceutical firms as a whole. We looked at panel dataset from 1999-2000 to2015-2016.The variables representing structural components, conduct factors and performance variables are based on literature documented in this field by Mishra P.\& Chandra T.(2010); Anh, T. T., Binh, D. T. T., \& Duong, N. V. (2014). Firm Size is generally has positive impact on profitability due to economies of scale and has been well documented by (Hall and Weiss, 1967; Scherer, 1973; Majumdar, 1997). Market Size is used as measure of the demand of company's product. Market Share is expected to increase firm's profitability and has been found to have U-shaped relationship (Feeny and Rogers 1999).McDonald (1999) found no significant relationship between profitability and market share of Australian manufacturing firms. Mergers and Acquisitions increase the market power (Steiner, 1975, Chatterjee, 1986).

We have adopted the following econometric equations:

Profitit $=\quad \alpha 0+\alpha 1$ sit $+\alpha 2$ mktszit $+\alpha 3$ frmszit $+\alpha 4$ Expi,t+ +55 Impi,t+ $\alpha 6$ Adi,t $+\alpha 7$ Rawi,t $+\alpha 8$ Poweri, $t+\alpha 9$ Wagei, $t+\alpha 10 M A i, t+\mathrm{u}$

where

- Profit is the ratio of profit after tax to sales offirms

- $\quad \mathrm{Si}$ is a measure of concentration and is measured as market share of firms in the industry (total market shares $\Sigma$ si of firms)

- $\quad$ Mktsz represents market size offirms.

- $\quad$ Frmsz represents firms size as proxied by its fixed assets.

- $\quad$ Exp is a variable representing Exportintensity.

- $\quad$ Imp is a variable representing Importintensity.

- $\mathrm{Adv}$ is a variable representing Advertisementintensity.

- Raw is a variable representing Raw material useintensity.

- Power is a variable representing Power useintensity.

- Wage is a variable representing Wageintensity.

- $M A t$ is a variable representing mergers andacquisitions.

\section{Research Findings:}

Using panel data regression model technique results found are tabulated below. The summary statistic is given in Table1 as follows:

Table1: Descriptive Statistics of the Model

\begin{tabular}{|l|l|l|l|l|}
\hline Variable & Mean & Std. Dev. & Min & Max \\
\hline Profit After Tax & 207.42 & 1918.48 & -8790 & 28850.7 \\
\hline Mktsize & 5.82 & 2.289402 & -2.30259 & 11.57629 \\
\hline Frmsize & 5.850888 & 2.270068 & -2.30259 & 12.654 \\
\hline Marketshare & 0.062893 & 0.1359 & 0 & 1 \\
\hline
\end{tabular}




\begin{tabular}{|l|l|l|l|l|}
\hline Totalassets & 4376.328 & 21106.77 & 0.1 & 313014 \\
\hline ExpInt & 0.408998 & 0.657225 & $6.84 \mathrm{E}-05$ & 9.924157 \\
\hline ImpInt & 0.333473 & 1.948209 & 0.000146 & 34.66667 \\
\hline AdvInt & 0.058349 & 0.129065 & 0 & 2.333333 \\
\hline Rawmaterial_Int & 0.587165 & 0.400426 & -0.56044 & 5 \\
\hline Power_useInt & 0.11792 & 0.537331 & 0.000253 & 9 \\
\hline WageInt & 0.455451 & 3.478904 & 0.005233 & 69 \\
\hline
\end{tabular}

Table2givestheRandomEffectsoftheestimatedregressionmodel.Theempiricalresultssuggest that the Wald Chi square value is statistically significant. Moreover, the value of $\mathrm{R}$ square is also reasonably high indicating the explanatory power of themodel.

The model suggests that the performance in terms of its sustainable profitability of a firm depends inversely on the firm size. This is due to X-inefficiency phenomenon, which contradicts the perceived general notion due to increased entry of competitive firms. Export Intensity is also statically significant and is positively associated with sustainable profitability.

Table2: Results of Random Effects Model

\begin{tabular}{|l|l|l|l|l|}
\hline Variable & Coefficient & $\begin{array}{l}\text { Std } \\
\text { Error }\end{array}$ & Z- Stat & value \\
\hline Intercept & $1.367082^{*}$ & 0.378644 & 3.61 & 0 \\
\hline Frmsize & -0.20186 & 0.092705 & -2.18 & 0.029 \\
\hline Mktsize & 0.12925 & 0.100082 & 1.29 & 0.197 \\
\hline ExpInt & $1.974815^{*}$ & 0.103702 & 19.04 & 0 \\
\hline ImpInt & $-1.79251^{*}$ & 0.339767 & -5.28 & 0 \\
\hline AdvInt & 1.026935 & 1.553451 & 0.66 & 0.509 \\
\hline RawmaterialInt & $-0.752^{* *}$ & 0.35916 & -2.09 & 0.036 \\
\hline Power_useInt & $-3.24723^{*}$ & 1.011816 & -3.21 & 0.001 \\
\hline WageInt & $-5.92995^{*}$ & 0.422775 & -14.03 & 0 \\
\hline Ma & -0.1807 & 0.194242 & -0.93 & 0.352 \\
\hline Marketshare & -0.06275 & 0.35818 & -0.18 & 0.861 \\
\hline Wald chi2 & 8606.02 & & & \\
\hline$R$-sq:within & 0.0545 & 0.9808 & & \\
\hline$R$-sqbetween & 0.9729 & & \\
\hline$R$-sqoverall & & & \\
\hline
\end{tabular}

* Statistically significant at 1 percent

** Statistically significant at 5 percent 
Import Intensity is also statically significant and is negatively associated with sustainable profitability which is quiet intuitive. Raw material use intensity, power use intensity and wage intensity are all statistically significant and showing negative relationship indicating their expenditure will give positive results in future. This is also cross checked taking lagged values which gives positive effect on sustainable profitability. Interestingly mergers and acquisition and market share show statistically insignificant relationship with sustainable profitability.

\section{Conclusion and Policy Suggestions:}

Regulatory framework modifications of 1990s and amendments in the Indian Patent Act of 1970 during 1999 , 2002 and 2005 has impacted the market structure of the Indian pharmaceutical industry. As there is deep connect between structure and market conduct there is an impact on conduct factors and performance of Indian pharmaceutical companies.

The results show that the performance in terms of its sustainable profitability of a firm depends inversely on the firm size. This is in accordance to the principle of X-inefficiency, which contradicts the perceived general notion due to increased entry of competitive firms. Export Intensity is also statically significant and is positively associated with sustainable profitability.

Import Intensity is also statically significant and is negatively associated with sustainable profitability which is quiet intuitive. Raw material use intensity, power use intensity and wage intensity are all statistically significant and showing negative relationship indicating their expenditure will give positive results in future. This is also cross checked taking lagged values which gives positive effect on sustainable profitability. Interestingly mergers and acquisition and market share show insignificant impact on profitability of the firms in the long run possibly due to the resultant entry of new firms into the market.

Therefore, Indian pharmaceutical companies do not benefit from mergers and acquisitions. Hence mergers and acquisitions in Indian pharmaceuticals are not detrimental to the benefits of the consumers. The competitive policies of the government seems to be sound enough to prevent monopolistic profits in Indian pharmaceutical industry

\section{References}

Ali, A. "Firm size and supply chain finance in Indian pharmaceutical industry: Relational firm analysis of size determinants and cash conversion cycle." Accounting 7.1 (2021): 197-206.

Anh, T. T., Binh, D. T. T., \& Duong, N. V. (2014). The structure-conduct-performance paradigm revisited: an empirical analysis for Vietnamese firms. In Proceedings of the VEAM: Vietnam Economists Annual Meeting, Ho Chi Minh City, Vietnam (Vol.7).

Baker, J. B., Woodward, P. A. (1998). Market Power and the Cross-industry Behaviour of Price around a Business Cycle Trough. Working Paper No. 221. Bureau ofEconomics. Federal Trade Commission.

Bain J. S. (1951). Relation of Profit Rate to Industry Concentration: American Manufacturing 1936-1940. Quarterly Journal of Economics. 65(3), pp. 293-325.

Basant, R. (2011). Intellectual property protection, regulation and innovation in developing economies: the case of the Indian pharmaceutical industry. Innovation and Development, 1(1), 115-133.

Berger, A. N. (1995). The Profit-Structure Relationship in Banking: Tests of Market-Power and EfficientStructure Hypotheses. Journal of Money, Credit and Banking. 27(2), pp. 404-431.

Bhardwaj, R. (2015). Relationship Between Competition Law and Intellectual Property Rights in India: a Case Study of Pharmaceutical Sector (Doctoral dissertation).

Brucker, E. (1970). A Microeconomic Approach to Banking Competition. Journalof Finance. 25(5), pp. 11331141.

Cabral, L. and Mata, J. (2003). On the evolution of the firm size distribution: Facts and Theory. Americal Economic Review, 93(4), 1075-1090.

Chatterjee, S (1986) Types of Synergy and Economic Value: The Impact of Acquisitions onMerging and Rival Firms, Strategic Management Journal, 7(2), pp. 119-139.

Demsetz, H. (1974). Two Systems of Belief about Monopoly. In H. Goldschmid, H.Michael Mann and J. Fred Weston, eds. Industrial Concentration: The New Learning.Boston: Little, Brown and Co., pp. 164-84.

Edward, F. R. (1964). Concentration in Banking and Its Effect on Business LoanRates. Review of Economic and Statistics. 46(3), pp. 294-300.

Evanoff, D., Fortier, L. (1988). Re-evaluation of the Structure-Conduct-Performance Paradigm in Banking. Journal of Financial Services Research. 1(3), pp.277-294.

Feeny, S. and Rogers, M. (1999) Market Share, Concentration and Diversification inFirm Sustainable profitability, Forthcoming Working Paper, (Melbourne: MelbourneInstitute).

Gilbert, A. (1984). Studies of Bank Market Structure and Competition: A Reviewand Evaluation. Journal of Money, Credit and Banking. 16, pp. 617-644. 
Gupta, V. K. (1983). A Simultaneous Determination of Structure, Conduct and Performance in Canadian Manufacturing. Oxford Economic Papers. 35, pp. 281-301.

Hall, M., Weiss, L.W. (1967) Average concentration ratios and industrial performance, Review of Economics and Statistics, 49 (3), pp. 319-331.

Isola, W. A., \& Mesagan, E. P. (2016). Determinants of pharmaceutical industry's performance in Nigeria. Managing Global Transitions, 14(3), 267-282.

Kale, D., \& Little, S. (2007). From imitation to innovation: The evolution of R\&D capabilities and learning processes in the Indian pharmaceutical industry. Technology Analysis \& Strategic Management, 19(5), 589609.

Katib, N. M. (2004). Market Structure and Performance in the Malaysian Banking Industry: A Robust Estimation. 8th Capital Market Conference. Indian Institute of Capital Market Paper.

Khambampati, U. S. (1996). Industrial concentration and performance: a study ofthe structure, conduct, and performance of Indian industry. New Delhi: OxfordUniversity Press.

Lim, H., \&Rokhim, R. (2020). Factors affecting profitability of pharmaceutical company: an Indonesian evidence. Journal of Economic Studies.

Lloyad-Williams, D. M., Molyneux, P., Thornton, J. (1994). Marketstructure and performance in Spanish banking. Journal of Banking and Finance. 18(3),pp. 433-443.

Majumdar, S. (1997) The Impact of Size and Age on Firm-Level Performance: Some Evidencefrom India, Review of Industrial Organization 12(2), pp. 231-241.

McDonald, J. T. (1999). The determinants of firm sustainable profitability in Australian manufacturing. Economic Record, 75(2),115-126.

Mishra, P., \& Chandra, T. (2010). Mergers, acquisitions and firms' performance: Experience of Indian pharmaceutical industry. Eurasian Journal of Business and Economics, 3(5),111-126.

Molyneux, P., Thornton, J. (1992). Determinants of European BankProfitability: A Note. Journal of Banking and Finance 16(6), pp.1173-1178.

Molyneux, P., Forbes, W. (1995). Market Structure and Performance in EuropeanBanking. Applied Economics. 27(2), pp.155-159.

Sahu, S. K. (2014). Globalization, WTO, and the Indian pharmaceutical industry. Asian Affairs: An American Review, 41(4), 172-202.

Scherer, F.M. (1973) The determinants of industrial plant size in six nations, Review ofEconomics and Statistics, 55 (2), pp.135-145.

Schmalensee, R. (1989). Inter-industry Studies of Structure and Performance. In R. Schmalensee and R. Willig (ed.) Handbook of Industrial Organization. Vol. 2, New York: North Holland. pp. 952-1009.

Steiner, Peter O. (1975) Mergers, Motives, Effects and Policies (Ann Arbor, MI: University of Michigan Press).

Vernon, J. R. (1971). Separation of ownership and control and profits rates, theevidence from banking: Comment. Journal of Financial and Quantitative Analysis. 6(1),pp. 615-625. 